\title{
Simvastatin, a Novel Stimulator of Eryptosis, the Suicidal Erythrocyte Death
}

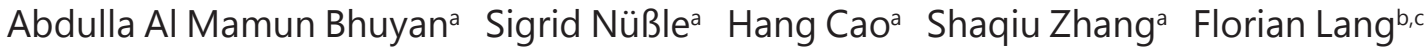 \\ aDepartment of Internal Medicine III, Eberhard-Karls-University of Tuebingen, ${ }^{b}$ Department of \\ Molecular Medicine II, Medical Faculty, Heinrich Heine University, Duesseldorf, 'Department of \\ Physiology I, Eberhard-Karls-University of Tuebingen, Germany
}

\section{Key Words}

Phosphatidylserine $\bullet$ Cell membrane scrambling • Oxidative stress $\bullet$ Calcium

\begin{abstract}
Background/Aims: The 3-hydroxy-3-methyl-glutaryl-Coenzyme A (HMG-CoA) reductase inhibitor simvastatin has been shown to trigger apoptosis of several cell types. The substance has thus been proposed as an additional treatment of malignancy. Similar to apoptosis of nucleated cells, erythrocytes may enter eryptosis, the suicidal erythrocyte death. Hallmarks of eryptosis include cell shrinkage and cell membrane scrambling with phosphatidylserine translocation to the extracellular face of the erythrocyte cell membrane. Signaling contributing to stimulation of eryptosis include increase of cytosolic $\mathrm{Ca}^{2+}$ activity $\left(\left[\mathrm{Ca}^{2+}\right]_{\mathrm{i}}\right)$, induction of oxidative stress, increase of ceramide abundance, and activation of SB203580-sensitive p38 kinase. The present study explored, whether simvastatin induces eryptosis and aimed to shed light on cellular mechanisms involved. Methods: Flow cytometry was employed to quantify phosphatidylserine exposure at the cell surface from annexin-V-binding, cell volume from forward scatter, $\left[\mathrm{Ca}^{2+}\right]_{i}$ from Fluo3-fluorescence, reactive oxygen species (ROS) abundance from DCFDA dependent fluorescence, and ceramide abundance utilizing specific antibodies. Hemolysis was estimated from hemoglobin concentration in the supernatant. Results: A $48 \mathrm{~h}$ exposure of human erythrocytes to simvastatin $(1 \mu \mathrm{g} / \mathrm{ml})$ significantly decreased the forward scatter, significantly augmented the percentage of annexin-V-binding cells, significantly increased Fluo3-fluorescence, and significantly enhanced DCFDA fluorescence. Simvastatin tended to increase ceramide abundance, an effect, however, escaping statistical significance. The effect of simvastatin on annexin- $V$-binding was significantly blunted by removal of extracellular $\mathrm{Ca}^{2+}$ and by addition of SB203580 $(2 \mu \mathrm{M})$. Conclusions: Simvastatin stimulates eryptosis, an effect at least in part due to $\mathrm{Ca}^{2+}$ entry, oxidative stress, and p38 kinase.
\end{abstract}

\section{Introduction}

Simvastatin, a 3-hydroxy-3-methyl-glutaryl-Coenzyme A (HMG-CoA) reductase inhibitor decreasing cholesterol synthesis [1], is widely used for the treatment of dyslipidemia with hypercholesterolemia [2-15]. Further putative therapeutic effects include decrease of 
hippocampal amyloid-beta abundance in Alzheimer's disease [16], anticoagulation [10], inhibition of inflammatory disease, such as asthma [1, 17-19], protection against contrastinduced nephropathy [20], protection of cardiac allografts against ischemia/reperfusion injury [21], as well as counteraction of osteoporosis and support of bone fracture healing [22, 23]. Side effects of simvastatin include rhabdomyolysis [6, 8, 24-29] and thrombocytopenia [30].

Simvastatin has been shown to stimulate apoptosis of neurons [31] and tumor cells [3239]. In view of its effect in tumor cells simvastatin was considered as a potential therapeutic option in malignancy [32, 35-37]. On the other hand, simvastatin may inhibit apoptosis of osteoblasts [22, 40].

Similar to apoptosis of nucleated cells, erythrocytes may enter eryptosis [41], the suicidal death of erythrocytes characerized by cell shrinkage [42] and by cell membrane scrambling with phosphatidylserine translocation to the outer face of the erythrocyte $[41,43]$ and release of exosomes [44]. Signaling stimulating eryptosis includes increase of cytosolic $\mathrm{Ca}^{2+}$ activity $\left(\left[\mathrm{Ca}^{2+}\right]_{\mathrm{i}}\right)[41,45]$, ceramide [46], caspases [41, 47, 48], G-protein Galphai2 [49], casein kinase $1 \alpha[41,50]$, Janus-activated kinase JAK3 [41,51], protein kinase C $[41,52]$, and p38 kinase $[41,53]$. Eryptosis is suppressed by AMP activated kinase AMPK $[41,54]$, cGMP-dependent protein kinase $[41,55]$, mitogen and stress activated kinase MSK1/2 [56], PAK2 kinase [41, 57] and sorafenib/sunitinib sensitive kinases [41, 58, 59]. Eryptosis could be triggered by a wide variety of cell stressors including hyperosmotic shock [41], oxidative stress [41], energy depletion [41], and a myriad of xenobiotics [41, 60-117]. Enhanced eryptosis is observed in multiple clinical conditions including iron deficiency [41], dehydration [118], hyperphosphatemia [119], vitamin D excess [70], chronic kidney disease (CKD) [120-124], hemolytic-uremic syndrome [125], diabetes mellitus [126], hepatic failure [94, 127], malignancy [128, 129], arteritis [130], sepsis [131], sickle-cell disease [41], betathalassemia [41], Hb-C and G6PD-deficiency [41], and Wilsons disease [132]. Eryptosis is further enhanced in elderly individuals [133], sensitive to erythrocyte age [107], and increased following extended storage of erythrocytes for transfusion [134].

To possibly uncover an effect of simvastatin on eryptosis, human erythrocytes from healthy volunteers were exposed to simvastatin and phosphatidylserine surface abundance, cell volume, $\left[\mathrm{Ca}^{2+}\right]_{\mathrm{i}^{\prime}}$, reactive oxygen species (ROS) and ceramide abundance determined by flow cytometry.

\section{Materials and Methods}

Erythrocytes, solutions and chemicals

Fresh Li-Heparin-anticoagulated blood samples were kindly provided by the blood bank of the University of Tübingen. The study is approved by the ethics committee of the University of Tübingen (184/2003 V). The blood was centrifuged at $120 \mathrm{~g}$ for $20 \mathrm{~min}$ at $21^{\circ} \mathrm{C}$ and the supernatant with platelets as well as leukocytes was disposed. Erythrocytes were incubated in vitro at a packed cell volume of $0.4 \%$ in Ringer solution containing (in $\mathrm{mM}$ ) $125 \mathrm{NaCl}, 5 \mathrm{KCl}, 1 \mathrm{MgSO}_{4}, 32 \mathrm{~N}$-2-hydroxyethylpiperazine-N-2-ethanesulfonic acid (HEPES; pH 7.4), 5 glucose, $1 \mathrm{CaCl}_{2}$, at $37^{\circ} \mathrm{C}$ for $48 \mathrm{~h}$. Where indicated, erythrocytes were exposed for $48 \mathrm{~h}$ to simvastatin (Sigma Aldrich, Hamburg, Germany). In order to estimate the impact of $\mathrm{Ca}^{2+}$ entry on simvastatin induced eryptosis, erythrocytes were exposed to simvastatin in the absence of extracellular $\mathrm{Ca}^{2+}$. To test for an involvement of p38 kinase, erythrocytes were exposed for 48 hours to a combination of simvastatin and p38 kinase inhibitor SB203580 (Tocris bioscience, Bristol, UK).

Annexin-V-binding and forward scatter

After incubation under the respective experimental condition, a $150 \mu \mathrm{l}$ cell suspension was washed in Ringer solution containing $5 \mathrm{mM} \mathrm{CaCl}_{2}$ and then stained with Annexin-V-FITC (1:200 dilution; ImmunoTools, Friesoythe, Germany) in this solution at $37^{\circ} \mathrm{C}$ for $15 \mathrm{~min}$ under protection from light. The annexin- $\mathrm{V}$ abundance at the erythrocyte surface was subsequently determined on a FACS Calibur (BD, Heidelberg, Germany). Annexin-V-binding was measured with an excitation wavelength of $488 \mathrm{~nm}$ and an emission 


\section{Cellular Physiology Cell Physiol Biochem 2017;43:492-506 \begin{tabular}{l|l|l} 
DOI: 10.1159/000480476 & $\begin{array}{l}\text { O 2017 The Author(s). Published by S. Karger AG, Basel } \\
\text { www.karger.com/cpb }\end{array}$
\end{tabular} \\ Al Mamun Bhuyan et al.: Simvastatin-Induced Eryptosis}

wavelength of $530 \mathrm{~nm}$. A marker (M1) was placed to set an arbitrary threshold between annexin-V-binding cells and control cells. The same threshold was used for untreated and simvastatin treated erythrocytes. The threshold of forward scatter was set at the default value of " 52 ".

Intracellular $\mathrm{Ca}^{2+}$

After incubation, erythrocytes were washed in Ringer solution and loaded with Fluo-3/AM (Biotium, Hayward, USA) in Ringer solution containing $5 \mathrm{mM} \mathrm{CaCl}_{2}$ and $5 \mu \mathrm{M}$ Fluo-3/AM. The cells were incubated at $37^{\circ} \mathrm{C}$ for $30 \mathrm{~min} . \mathrm{Ca}^{2+}$-dependent fluorescence intensity was measured with an excitation wavelength of $488 \mathrm{~nm}$ and an emission wavelength of $530 \mathrm{~nm}$ on a FACS Calibur. Afterwards, the geomean of the $\mathrm{Ca}^{2+}$ dependent fluorescence was determined.

Reactive oxygen species (ROS)

Oxidative stress was determined utilizing 2',7'-dichlorodihydrofluorescein diacetate (DCFDA). After incubation, a $150 \mu$ l suspension of erythrocytes was washed in Ringer solution and stained with DCFDA (Sigma, Schnelldorf, Germany) in Ringer solution containing DCFDA at a final concentration of $10 \mu \mathrm{M}$. Erythrocytes were incubated at $37^{\circ} \mathrm{C}$ for $30 \mathrm{~min}$ in the dark and washed two times in Ringer solution. The DCFDA-loaded erythrocytes were resuspended in $200 \mu$ l Ringer solution and ROS-dependent fluorescence intensity was measured at an excitation wavelength of $488 \mathrm{~nm}$ and an emission wavelength of $530 \mathrm{~nm}$ on a FACS Calibur (BD). Subsequently, the geomean of the DCFDA dependent fluorescence was determined.

\section{Ceramide abundance}

For the determination of ceramide, a monoclonal antibody-based assay was used. To this end, cells were stained for $1 \mathrm{~h}$ at $37^{\circ} \mathrm{C}$ with $1 \mu \mathrm{g} / \mathrm{ml}$ anti ceramide antibody (clone MID 15B4, Enzo Life Science $\mathrm{GmbH}$, Lörrach, Germany) in PBS containing $0.1 \%$ bovine serum albumin (BSA) at a dilution of 1:10. The samples were washed twice with PBS-BSA. The cells were stained for 30 min with polyclonal fluorescein isothiocyanate (FITC) conjugated goat anti-mouse IgG and IgM specific antibody (Pharmingen, Hamburg, Germany) diluted 1:50 in PBS-BSA. Unbound secondary antibody was removed by repeated washing with PBS-BSA. The samples were analyzed by flow cytometric analysis with an excitation wavelength of $488 \mathrm{~nm}$ and an emission wavelength of $530 \mathrm{~nm}$. As a control, secondary antibody alone was used.

Hemolysis

For the determination of hemolysis, the samples were centrifuged ( 3 min at $1600 \mathrm{rpm}$ in room temperature) after incubation, and the supernatants were harvested. As a measure of hemolysis, the hemoglobin $(\mathrm{Hb})$ concentration of the supernatant was determined photometrically at $405 \mathrm{~nm}$. The absorption of the supernatant of erythrocytes lysed in distilled water was defined as $100 \%$ hemolysis.

Statistics

Data are expressed as arithmetic means \pm SEM. As indicated in the figure legends, statistical analysis was made using ANOVA with Tukey's test as post-test and $t$ test as appropriate. $\mathrm{n}$ denotes the number of different erythrocyte specimens studied. Since different erythrocyte specimens used in distinct experiments are differently susceptible to triggers of eryptosis, the same erythrocyte specimens have been used for control and experimental conditions.

\section{Results}

In order to test, whether simvastatin modifies eryptosis, erythrocytes drawn from healthy individuals were exposed for $48 \mathrm{~h}$ to Ringer solution without or with simvastatin $(0.5$ $-2 \mu \mathrm{g} / \mathrm{ml}$ ). Eryptotic erythrocytes were identified from cell shrinkage and cell membrane scrambling.

Cell volume was estimated from forward scatter in flow cytometry. As illustrated in Fig. 1A,B, a $48 \mathrm{~h}$ exposure to simvastatin decreased the forward scatter, an effect reaching statistical significance at $1 \mu \mathrm{g} / \mathrm{ml}$ simvastatin concentration. Thus, simvastatin triggered cell shrinkage. Along those lines, at all simvastatin concentrations tested, simvastatin 
Fig. 1. Effect of Simvastatin on erythrocyte forward scatter. A. Original histograms of forward scatter of erythrocytes following exposure for $48 \mathrm{~h}$ to Ringer solution without (grey area) and with (black line) presence of $2 \mu \mathrm{g} / \mathrm{ml}$ Simvastatin. B. Arithmetic means \pm SEM $(n=14)$ of the erythrocyte forward scatter (FSC) following incubation for $48 \mathrm{~h}$ in Ringer solution without (white bar) or with (black bars) Simvastatin (0.5 - $2 \mu \mathrm{g}$ / $\mathrm{ml}$ ) or solvant DMSO alone (grey bar). C,D. Arithmetic means \pm SEM of the percentage of erythrocytes with (C) FSC $<200$ or (D) FSC $>800$ following incubation for $48 \mathrm{~h}$ to Ringer solution without (white bar) or with (black bars) Simvastatin $(0.5-2 \mu \mathrm{g} / \mathrm{ml})$ or

A

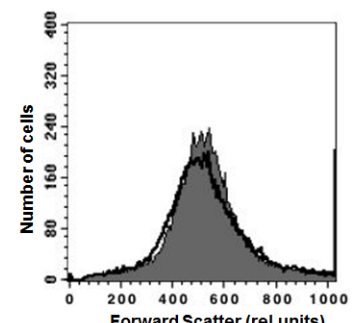

C

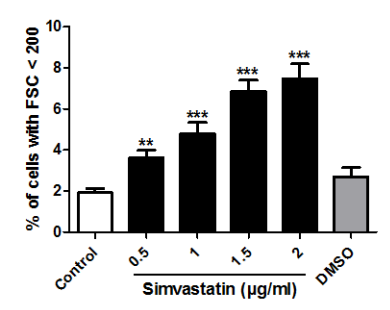

B

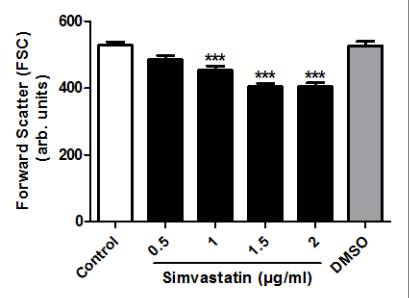

D

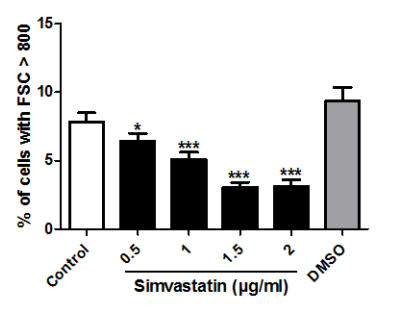
solvant DMSO alone (grey bar). ${ }^{*}(\mathrm{p}<0.05),{ }^{* *}(\mathrm{p}<0.01),{ }^{* * *}(\mathrm{p}<0.001)$ indicates significant difference from the absence of simvastatin (ANOVA).

Fig. 2. Effect of simvastatin on phosphatidylserine exposure. A. Original histogram of annexin-V-binding of erythrocytes following exposure for $48 \mathrm{~h}$ to Ringer solution without (grey area) and with (black line) presence of $2 \mu \mathrm{g} / \mathrm{ml}$ simvastatin. B. Arithmetic means \pm SEM $(n=14)$ of erythrocyte annexin-V-binding following incubation for $48 \mathrm{~h}$ in Ringer solution without (white bar) or with (black bars)

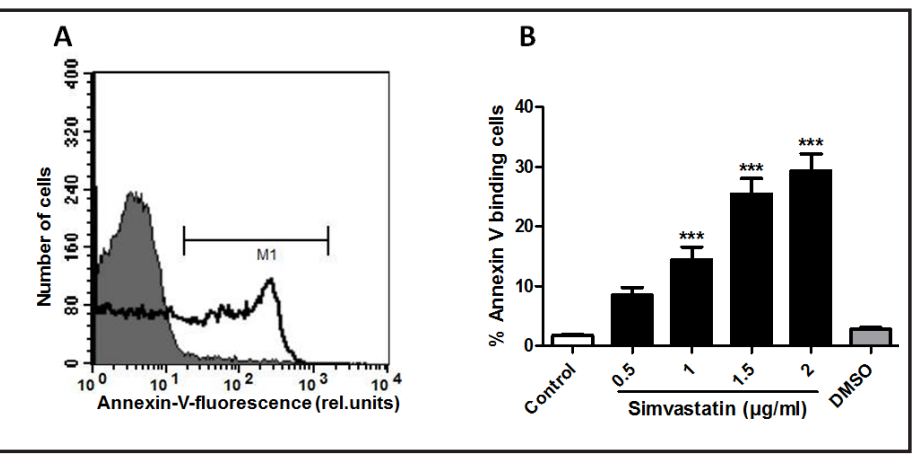
simvastatin $(0.5-2 \mu \mathrm{g} / \mathrm{ml})$. For comparison, the effect of the solvent DMSO is shown (grey bar). ${ }^{* * *}(\mathrm{p}<0.001)$ indicates significant difference from the absence of simvastatin (ANOVA).

significantly increased the percentage of shrunken erythrocytes (Fig. 1C) and significantly decreased the percentage of erythrocytes with large volumes (Fig. 1D).

Cell membrane scrambling with phosphatidylserine translocation to the cell surface was evidenced from annexin-V-binding to phosphatidylserine, as determined by flow cytometry. As illustrated by Fig. 2A,B, a $48 \mathrm{~h}$ exposure to simvastatin increased the percentage of phosphatidylserine exposing erythrocytes, an effect reaching statistical significance at $1 \mu \mathrm{g} /$ ml simvastatin.

Eryptosis could be triggered by increase of cytosolic $\mathrm{Ca}^{2+}$ activity $\left(\left[\mathrm{Ca}^{2+}\right]_{\mathrm{i}}\right)$. Fluo3 fluorescence was thus employed in order to quantify $\left[\mathrm{Ca}^{2+}\right]_{\mathrm{i}}$. As illustrated in Fig. 3A,B, a 48 $\mathrm{h}$ exposure to simvastatin increased the Fluo3 fluorescence, an effect reaching statistical significance at $2 \mu \mathrm{g} / \mathrm{ml}$ simvastatin.

In order to test, whether the increase of $\left[\mathrm{Ca}^{2+}\right]_{\mathrm{i}}$ required entry of extracellular $\mathrm{Ca}^{2+}$, erythrocytes were incubated for $48 \mathrm{~h}$ in the absence or presence of $2 \mu \mathrm{g} / \mathrm{ml}$ simvastatin in the presence or nominal absence of extracellular $\mathrm{Ca}^{2+}$. As illustrated in Fig. 4, removal of extracellular $\mathrm{Ca}^{2+}$ tended to blunt the effct of simvastatin on $\left[\mathrm{Ca}^{2+}\right]_{\mathrm{i}}$, an effect, however, not reaching statistical significance. Exposure of erythrocytes for $48 \mathrm{~h}$ to simvastatin $(2 \mu \mathrm{g} / \mathrm{ml})$ significantly increased the Fluo3 fluorescence both, in the presence and nominal absence of extracellular $\mathrm{Ca}^{2+}$ 

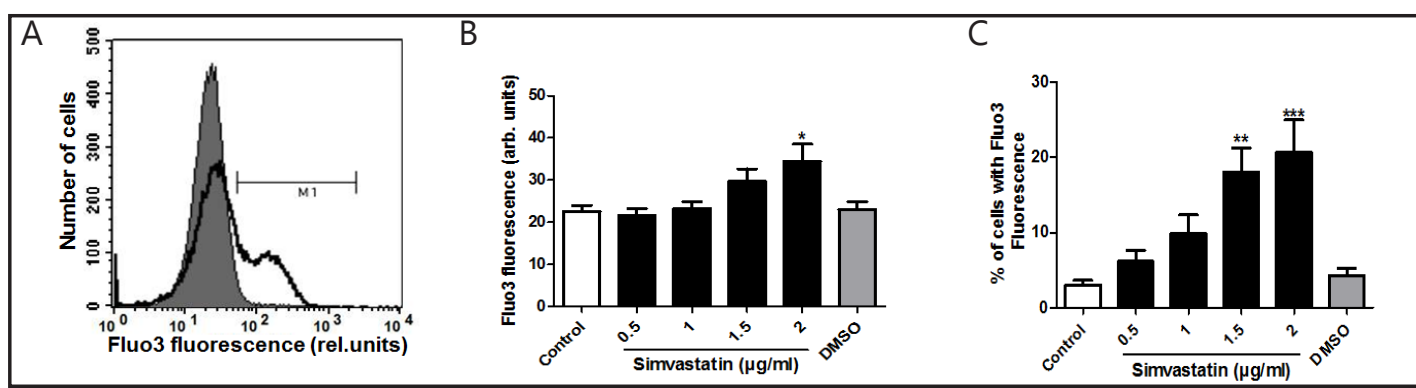

Fig. 3. Effect of simvastatin on cytosolic $\mathrm{Ca}^{2+}$ activity. A. Original histogram of Fluo3 fluorescene reflecting erythrocyte cytosolic $\mathrm{Ca}^{2+}$ activity following exposure for $48 \mathrm{~h}$ to Ringer solution without (grey area) and with (black line) presence of $2 \mu \mathrm{g} / \mathrm{ml}$ simvastatin. B. Arithmetic means \pm SEM $(\mathrm{n}=14)$ of erythrocyte Fluo3 fluorescence following incubation for $48 \mathrm{~h}$ in Ringer solution without (white bar) or with (black bars) simvastatin $(0.5-2 \mu \mathrm{g} / \mathrm{ml})$. For comparison, the effect of the solvent DMSO is shown (grey bar). C. Arithmetic means \pm SEM of the percentage of erythrocytes with enhanced Fluo3 fluorescence following incubation for $48 \mathrm{~h}$ in Ringer solution without (white bar) or with (black bars) Simvastatin $(0.5-2 \mu \mathrm{g} / \mathrm{ml})$ or solvant DMSO alone (grey bar). ${ }^{*}(\mathrm{p}<0.05),{ }^{* *}(\mathrm{p}<0.01),{ }^{* * *}(\mathrm{p}<0.001)$ indicates significant difference from the absence of simvastatin (ANOVA).

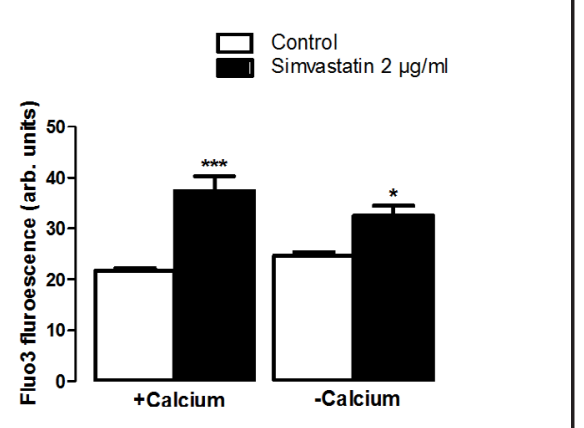

Fig. 4. Sensitivity of simvastatin-induced increase of cytosolic $\mathrm{Ca}^{2+}$ activity to presence or nominal absence of extracellular $\mathrm{Ca}^{2+}$. Arithmetic means $\pm \mathrm{SEM}$ ( $n=19$ ) of erythrocyte Fluo3 fluorescence following incubation for 48 hours in Ringer solution without (white bars) or with (black bars) simvastatin ( $2 \mu \mathrm{g} /$ $\mathrm{ml}$ ) in the presence (left bars, $+\mathrm{Ca}^{2+}$ ) and absence (right bars, $\left.-\mathrm{Ca}^{2+}\right)$ of $\mathrm{Ca}^{2+} .{ }^{*}(\mathrm{p}<0.05),{ }^{* * *}(\mathrm{p}<0.001)$ indicates significant difference from the absence of simvastatin (ANOVA).

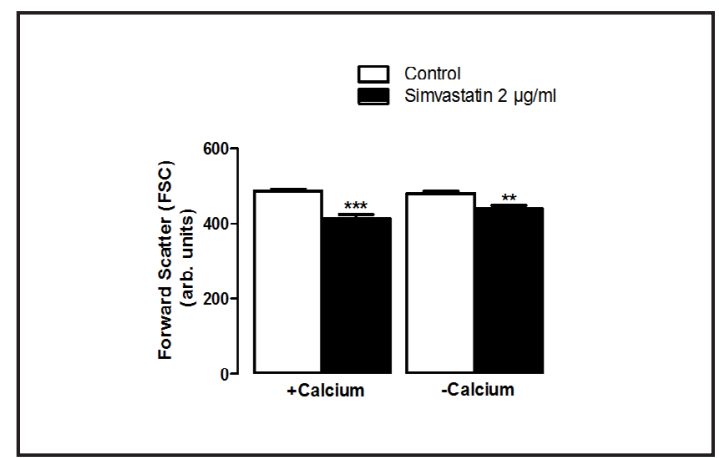

Fig. 5. Simvastatin-inducd erythrocyte shrinkage in presence or nominal absence of extracellular $\mathrm{Ca}^{2+}$. Arithmetic means \pm SEM $(n=24)$ of erythrocyte Fluo3 fluorescence following incubation for 48 hours in Ringer solution without (white bars) or with (black bars) simvastatin $(2 \mu \mathrm{g} / \mathrm{ml})$ in the presence (left bars, $+\mathrm{Ca}^{2+}$ ) and nominal absence (right bars, $\left.-\mathrm{Ca}^{2+}\right)$ of $\mathrm{Ca}^{2+} . * *(\mathrm{p}<0.01),{ }^{* * *}(\mathrm{p}<0.001)$ indicates significant difference from the absence of simvastatin (ANOVA).

As illustrated in Fig. 5, a $48 \mathrm{~h}$ treatment of erythrocytes with $2 \mu \mathrm{g} / \mathrm{ml}$ of simvastatin deceased the forward scatter significantly in both, the presence and absence of extracellular $\mathrm{Ca}^{2+}$. The effect tended to be smaller in the nominal absence than in the presence of extracellular $\mathrm{Ca}^{2+}$, a difference, however, not reaching statistical significance.

In order to test whether simvastatin-induced cell membrane scrambling required entry of extracellular $\mathrm{Ca}^{2+}$, erythrocytes were incubated for $48 \mathrm{~h}$ in the absence or presence of 2 $\mu \mathrm{g} / \mathrm{ml}$ simvastatin in the presence or nominal absence of extracellular $\mathrm{Ca}^{2+}$. As illustrated in Fig. 6A-C, removal of extracellular $\mathrm{Ca}^{2+}$ significantly blunted the effect of simvastatin on annexin-V-binding. However, even in the nominal absence of extracellular $\mathrm{Ca}^{2+}$, simvastatin significantly increased the percentage of annexin-V-binding erythrocytes. Thus, the simvastatin-induced cell membrane scrambling was in part but not completely due to entry of extracellular $\mathrm{Ca}^{2+}$. 


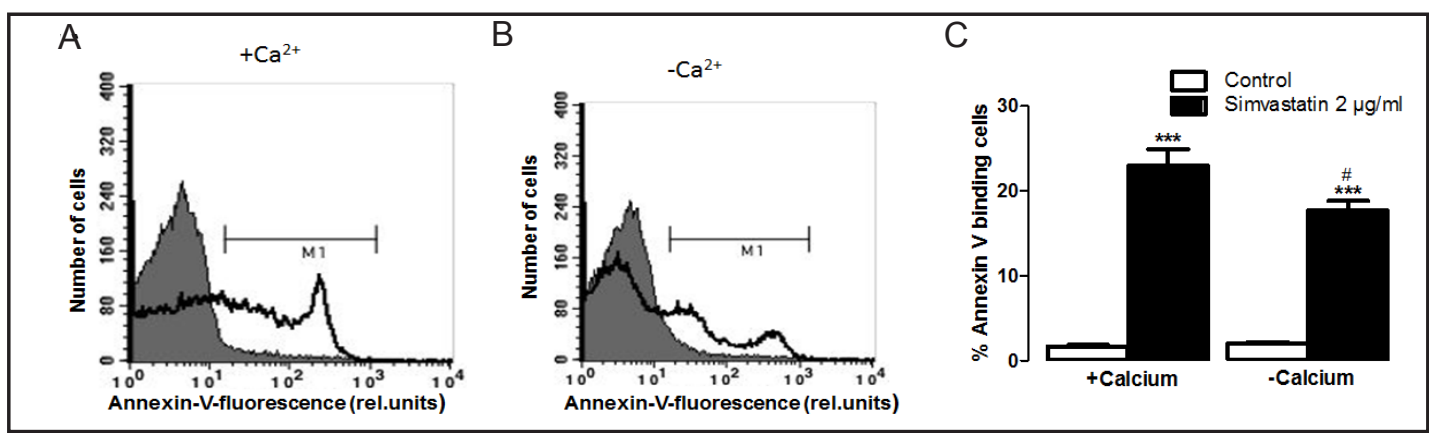

Fig. 6. $\mathrm{Ca}^{2+}$ sensitivity of simvastatin-induced phosphatidylserine exposure. A,B. Original histograms of annexin-V-binding of erythrocytes following exposure for $48 \mathrm{~h}$ to Ringer solution without (grey areas) and with (black lines) simvastatin $(2 \mu \mathrm{g} / \mathrm{ml})$ in the presence (A) and absence (B) of extracellular $\mathrm{Ca}^{2+}$. C. Arithmetic means \pm SEM $(n=18)$ of annexin-V-binding of erythrocytes after a $48 \mathrm{~h}$ treatment with Ringer solution without (white bars) or with (black bars) simvastatin $(2 \mu \mathrm{g} / \mathrm{ml})$ in the presence (left bars, $\left.+\mathrm{Ca}^{2+}\right)$ and absence (right bars, $\left.-\mathrm{Ca}^{2+}\right)$ of $\mathrm{Ca}^{2+} . * * *(\mathrm{p}<0.001)$ indicates significant difference from the absence of simvastatin, $\#(\mathrm{p}<0.05)$ indicates significant difference from the presence of $\mathrm{Ca}^{2+}$ (ANOVA).

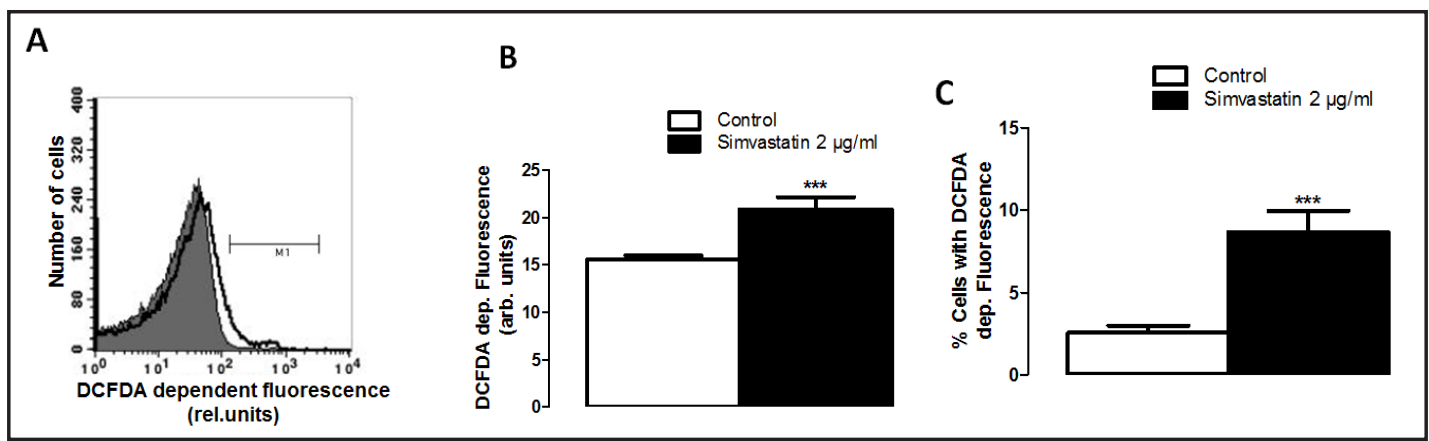

Fig. 7. Effect of simvastatin on reactive oxygen species. A. Original histogram of DCFDA fluorescence in erythrocytes following exposure for $48 \mathrm{~h}$ to Ringer solution without (grey area) and with (black line) presence of $2 \mu \mathrm{g} / \mathrm{ml}$ simvastatin. B. Arithmetic means \pm SEM $(\mathrm{n}=22)$ of DCFDA fluorescence in erythrocytes following incubation for $48 \mathrm{~h}$ to Ringer solution without (white bar) or with (black bar) simvastatin $(1 \mu \mathrm{g} /$ $\mathrm{ml})$. C. Arithmetic means \pm SEM of the percentage of erythrocytes with enhanced DCFDA fluorescence following incubation for $48 \mathrm{~h}$ to Ringer solution without (white bar) or with (black bars) Simvastatin (0.5 - 2 $\mu \mathrm{g} / \mathrm{ml}$ ) or solvant DMSO alone (grey bar). ${ }^{* * *}(\mathrm{p}<0.01)$ indicates significant difference from the absence of simvastatin (unpaired $t$ test).

Fig. 8. Effect of simvastatin on reactive oxygen species in presence or nominal absence of extracellular $\mathrm{Ca}^{2+}$. Arithmetic means \pm SEM $(\mathrm{n}=19)$ of erythrocyte DCFDA fluorescence following incubation for 48 hours in Ringer solution without (white bars) or with (black bars) simvastatin $(2 \mu \mathrm{g} / \mathrm{ml})$ in the presence (left bars, $+\mathrm{Ca}^{2+}$ ) and absence (right bars, $\left.-\mathrm{Ca}^{2+}\right)$ of $\mathrm{Ca}^{2+} . *(\mathrm{p}<0.05),{ }^{* * *}(\mathrm{p}<0.001)$ indicates significant difference from the absence of simvastatin, $\# \#(\mathrm{p}<0.01)$ indicates significant difference from the abscence of $\mathrm{Ca}^{2+}$ (ANOVA).

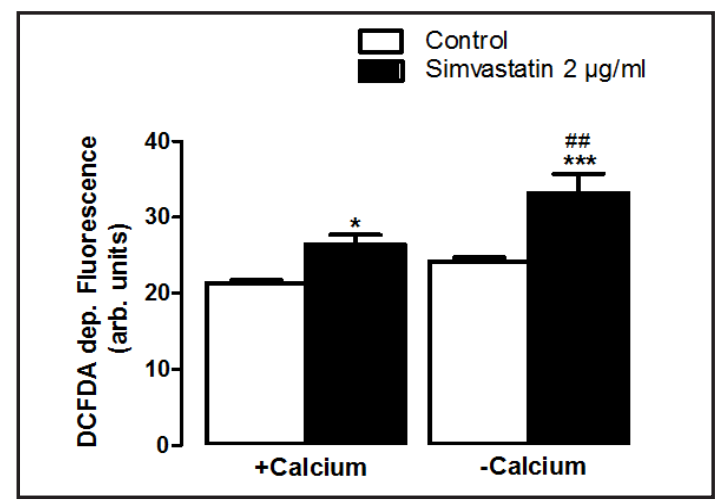

Eryptosis is further stimulated by oxidative stress. The abundance of reactive oxygen species (ROS) was thus quantified utilizing $2^{\prime}, 7^{\prime}$-dichlorodihydrofluorescein diacetate (DCFDA). As illustrated in Fig. 7A,B, a $48 \mathrm{~h}$ exposure to simvastatin $(2 \mu \mathrm{g} / \mathrm{ml})$ increased the average DCFDA fluorescence of erythrocytes from $15.6 \pm 0.4$ a.u. $(\mathrm{n}=22)$ to $20.8 \pm 1.3$ a.u. 


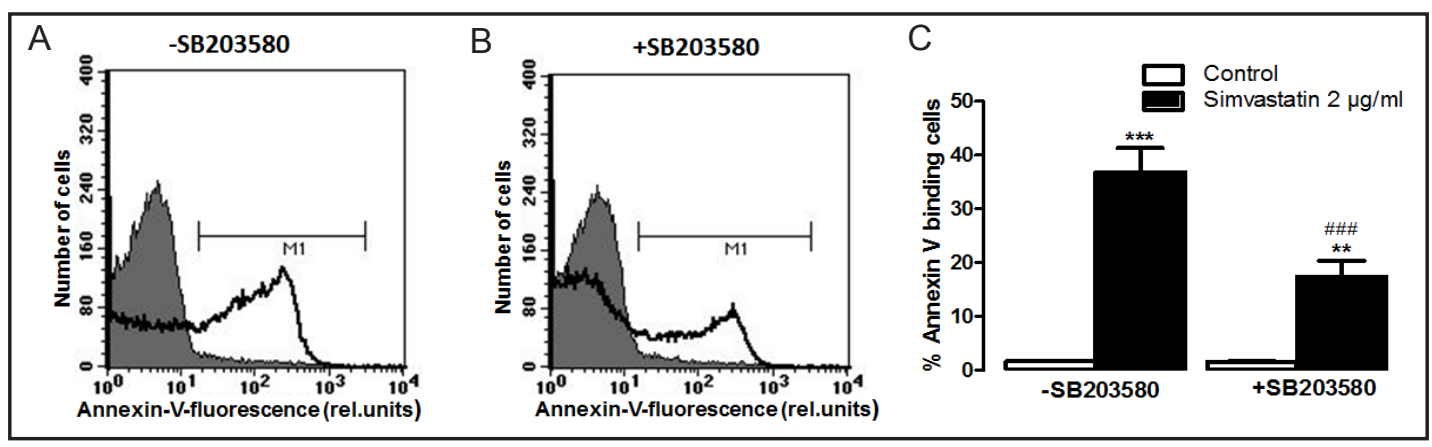

Fig. 9. SB203580 sensitivity of simvastatin-induced phosphatidylserine exposure. A,B. Original histograms of annexin-V-binding of erythrocytes following exposure for 48 hours to Ringer solution without (grey areas) and with (black lines) simvastatin $(2 \mu \mathrm{g} / \mathrm{ml})$ in the absence (A) and presence (B) of p38 kinase inhibitor SB203580 $(2 \mu \mathrm{M})$. C. Arithmetic means \pm SEM $(n=8)$ of annexin-V-binding of erythrocytes after a 48 hours treatment with Ringer solution without (white bars) or with (black bars) simvastatin $(2 \mu \mathrm{g} /$ $\mathrm{ml}$ ) in the absence (left bars, - SB203580) and presence (right bars, + SB203580) of p38 kinase inhibitor SB203580 $(2 \mu \mathrm{M}) .{ }^{* *}(\mathrm{p}<0.01),{ }^{* * *}(\mathrm{p}<0.001)$ indicates significant difference from the absence of simvastatin, $\# \# \#(p<0.001)$ indicates significant difference from the absence of SB203580 (2 $\mu \mathrm{M})$ (ANOVA).

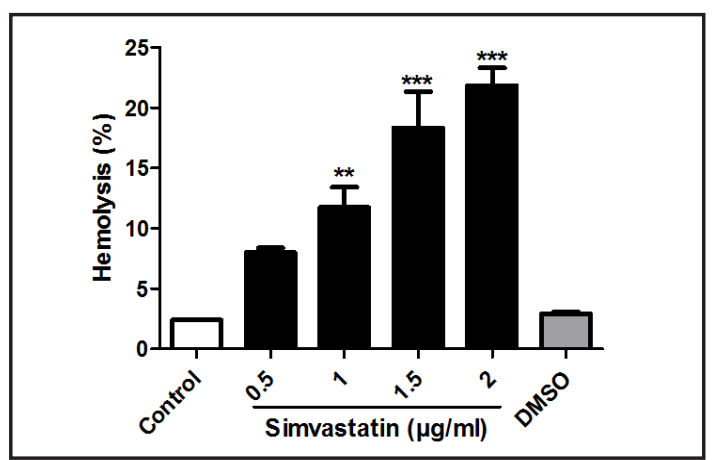

Fig. 10. Effect of simvastatin on hemolysis. Arithmetic means \pm SEM $(n=5)$ of erythrocyte hemolysis following incubation for $48 \mathrm{~h}$ to Ringer solution without (white bar) or with (black bars) simvastatin $(0.5$ - $2 \mu \mathrm{g} / \mathrm{ml}$ ). For comparison, the effect of the solvent DMSO is shown (grey bar). ${ }^{* *}(\mathrm{p}<0.01),{ }^{* * *}(\mathrm{p}<0.001)$ indicates significant difference from the absence of simvastatin (ANOVA).

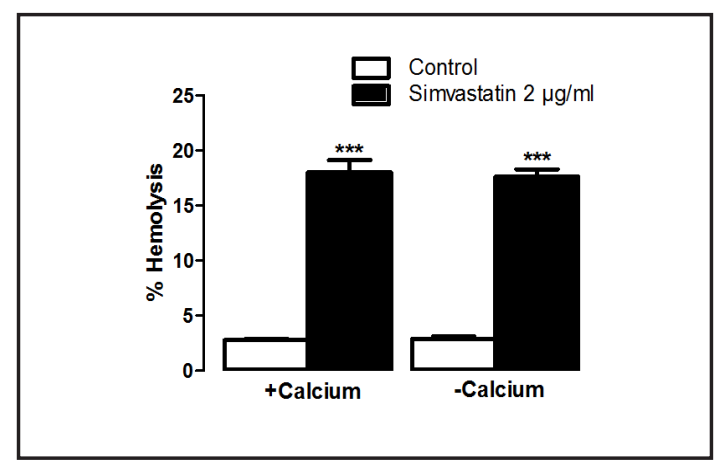

Fig. 11. Simvastatin-induced hemolysis in presence or nominal absence of extracellular $\mathrm{Ca}^{2+}$. Arithmetic means \pm SEM $(n=10)$ of the percentage hemolytic erythrocytes following incubation for 48 hours in Ringer solution without (white bars) or with (black bars) simvastatin $(2 \mu \mathrm{g} / \mathrm{ml})$ in the presence (left bars, $+\mathrm{Ca}^{2+}$ ) and absence (right bars, $-\mathrm{Ca}^{2+}$ ) of $\mathrm{Ca}^{2+}$. $* * *(\mathrm{p}<0.001)$ indicates significant difference from the absence of simvastatin (ANOVA).

$(\mathrm{n}=22)$. Moreover, simvastatin significantly increased the percentage of erythrocytes with high DCFDA fluorescence (Fig. 7C). The observations suggest that simvastatin did induce oxidative stress.

Again, oxidative stress was measured following incubation for $48 \mathrm{~h}$ in the absence or presence of $2 \mu \mathrm{g} / \mathrm{ml}$ simvastatin in the presence or nominal absence of extracellular $\mathrm{Ca}^{2+}$. As illustrated in Fig. 8, DCFDA fluorescence of erythrocytes significantly increased both, in the presence and absence of extracellular calcium. The average DCFDA fluorescence reached significantly higher values in the absence than in the presence of extracellular $\mathrm{Ca}^{2+}$.

A further stimulator of eryptosis is ceramide. Ceramide abundance at the erythrocyte surface was thus quantified utilizing specific antibodies. As a result, the ceramide abundance tended to be higher following exposure to $2 \mu \mathrm{g} / \mathrm{ml}$ simvastatin $(8.72 \pm 0.34$ a.u., $\mathrm{n}=15)$ than following incubation in the absence of simvastatin (7.77 \pm 0.32 a.u., $n=15)$, a difference, however, not reaching statistical significance. 


\section{Cellular Physiology Cell Physiol Biochem 2017;43:492-506

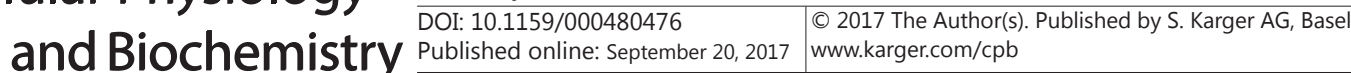

Al Mamun Bhuyan et al.: Simvastatin-Induced Eryptosis

To explore, whether the effects of simvastatin involved p38 kinase activity, the influence of simvastatin on annexin-V-binding was tested in the absence and presence of p38 kinase inhibitor SB203580. As illustrated in Fig. 9, SB203580 (2 $\mu \mathrm{M})$ significantly blunted the effect of simvastatin $(2 \mu \mathrm{g} / \mathrm{ml})$ on annexin-V-binding. However, even in the presence of SB203580, simvastatin significantly increased the percentage of annexin-V-binding erythrocytes.

A final series of experiments explored the influence of simvastatin on hemolysis. The percentage of hemolytic cells was quantified from the hemoglobin concentration in the supernatant. As illustrated in Fig. 10, a $48 \mathrm{~h}$ exposure to simvastatin increased the percentage of hemolytic erythrocytes, an effect reaching statistical significance at $1 \mu \mathrm{g} / \mathrm{ml}$ simvastatin.

Again the role of extracellular $\mathrm{Ca}^{2+}$ was tested by incubation for $48 \mathrm{~h}$ in the absence or presence of $2 \mu \mathrm{g} / \mathrm{ml}$ simvastatin in the presence or nominal absence of extracellular $\mathrm{Ca}^{2+}$. As illustrated Fig. 11, the percentage of hemolytic erythrocytes increased significantly to virtually the same extent in the presence and absence of extracellular $\mathrm{Ca}^{2+}$.

\section{Discussion}

The present observations reveal that simvastatin triggers erythrocyte shrinkage and cell membrane scrambling with phosphatidylserine translocation to the erythrocyte surface. Accordingly, simvastatin does not only trigger apoptosis, the suicidal death of nucleated cells [31-39], but by the same token triggers eryptosis, the suicidal erythrocyte death. The simvastatin concentrations required for the stimulation of eryptosis were in the range of concentrations $(0.9 \mu \mathrm{g} / \mathrm{ml})$ measured in the plasma of patients [39].

The effect of simvastatin on cell volume and cell membrane scrambling was paralleled by an increase of cytosolic $\mathrm{Ca}^{2+}$ activity $\left(\left[\mathrm{Ca}^{2+}\right]_{\mathrm{i}}\right)$. Moreover, the effect of simvastatin on cell membrane scrambling was partially blunted by removal of extracellular $\mathrm{Ca}^{2+}$, an observation pointing to a role of $\mathrm{Ca}^{2+}$ entry in the triggering of eryptosis. However, simvastatin triggered cell membrane scrambling even in the nominal absence of extracellular $\mathrm{Ca}^{2+}$, an observation suggesting the participation of additional mechanisms in simvastatin induced cell membrane scrambling. It must be kept in mind that removal of $\mathrm{Ca}^{2+}$ from and addition of EDTA to the Ringer solution (nominal absence of $\mathrm{Ca}^{2+}$ ) does not completely eliminate extracellular $\mathrm{Ca}^{2+}$. We cannot rule out that residual extracellular $\mathrm{Ca}^{2+}$ enters the cell and elicits the observed effects.

Cells could be sensitized for the scrambling effect of $\mathrm{Ca}^{2+}$ by ceramide [41]. Simvastatin treatment tended to increase the ceramide abundance. The effect did, however, not reach statistical significance.

Simvastatin significantly enhanced the abundance of reactive oxygen species, a well known trigger of eryptosis [41]. Simvastatin is therefore partially effective by inducing oxidative stress. Similar to the triggring effect of simvastatin on apoptosis of osteosarcoma cells [135], the stimulation of eryptosis by simvastatin on cell membrane scrambling requires apparently activity of p38 kinase, which is known to participate in the orchestration of eryptosis [53]. Accordingly, the effect of simvastatin on annexin-V-binding is significantly blunted in the presence of p38 kinase inhibitor SB203580.

The simvastatin-induced erythrocyte shrinkage was not significantly blunted in the nominal absence of extracellular $\mathrm{Ca}^{2+}$. This observation does not rule out the involvement of $\mathrm{Ca}^{2+}$ entry. An increase of $\left[\mathrm{Ca}^{2+}\right]_{\mathrm{i}}$ activates $\mathrm{Ca}^{2+}$-sensitive $\mathrm{K}^{+}$channels followed by $\mathrm{K}^{+}$exit, cell membrane hyperpolarization, $\mathrm{Cl}^{-}$exit and thus cellular loss of $\mathrm{KCl}$ with water [42]. Whether additional factors contribute to simvastatin induced erythrocyte shrinkage, remained elusive The present experiments cannot rule out the participation of further mechanisms in the stimulation of cell membrane scrambling and cell shrinkage following simvastatin treatment of erythrocytes.

Simvastatin further triggered hemolysis, pointing to disruption of the cell membrane. The function of eryptosis is the removal of defective erythrocytes from circulating blood prior to hemolysis [41]. Without timely removal of defective erythrocytes hemoglobin released following hemolysis passes the renal glomerular filter, precipitates in the acidic lumen of renal tubules, occludes nephrons and may thus lead to renal failure [136]. 


\section{Cellular Physiology Cell Physiol Biochem 2017;43:492-506 \begin{tabular}{l|l|l} 
and Biochemist 10.1159/000480476 & $\begin{array}{l}\text { C } 2017 \text { The Author(s). Published by S. Karger AG, Basel } \\
\text { www.karger.com/cpb }\end{array}$ \\
\hline
\end{tabular}}

Al Mamun Bhuyan et al.: Simvastatin-Induced Eryptosis

The clearance of phosphatidylserine exposing erythrocytes may result in the development of anemia. A combined therapy with simvastatin and cetuximab frequently leads to anemia [137]. However, we did not find reports of anemia following treatment with simvastatin alone. Anemia develops only, when the loss of erythrocytes surpasses the formation of new erythrocytes by erythropoiesis [41]. It should further be kept in mind that simvastatin decreases plasma concentrations of C-reactive protein (CRP) [138], a stimluator of eryptosis [139]. Thus the direct stimulation of eryptosis may be attenuated by the indirect decrease of CRP-induced eryptosis.

Besides its potential effect on anemia, eryptosis may interfere with microcirculation [46, 140-144], as phosphatidylserine exposing erythrocytes adhere to other phosphatidylserine exposing erythrocytes [145] and the vascular wall [146], stimulate blood clotting and trigger thrombosis $[140,147,148]$. The present observations may thus not only be relevant for development of anemia but may suggest to carefully consider the risk of thrombosis following simvastatin treatment. This may be particularly important in patients suffering from clinical disorders associated with enhanced eryptosis. However, the present data cannot be taken as evidence that simvastatin treatment triggers thrombosis.

In conclusion, simvastatin stimulates $\mathrm{Ca}^{2+}$ entry into erythrocytes, triggers oxidative stress and thus triggers erythrocyte shrinkage and erythrocyte cell membrane scrambling, the hallmarks of eryptosis, the suicidal death of erythrocytes.

\section{Acknowledgements}

The authors acknowledge the meticulous preparation of the manuscript by Lejla Subasic. The study was supported by the Deutsche Forschungsgemeinschaft and Open Access Publishing Fund of Tuebingen University.

\section{Disclosure Statement}

None.

\section{References}

1 Tulbah AS, Ong HX, Colombo P, Young PM, Traini D: Could simvastatin be considered as a potential therapy for chronic lung diseases? A debate on the pros and cons. Expert Opin Drug Deliv 2016;13:1407-1420.

$\longrightarrow 2$ Tarantino N, Santoro F, De Gennaro L, Correale M, Guastafierro F, Gaglione A, Di Biase M, Brunetti ND: Fenofibrate/simvastatin fixed-dose combination in the treatment of mixed dyslipidemia: safety, efficacy, and place in therapy. Vasc Health Risk Manag 2017;13:29-41.

3 Kei AA, Filippatos TD, Elisaf MS: The safety of ezetimibe and simvastatin combination for the treatment of hypercholesterolemia. Expert Opin Drug Saf 2016;15:559-569.

-4 Thomopoulos C, Skalis G, Michalopoulou H, Tsioufis C, Makris T: Effect of Low-Density Lipoprotein Cholesterol Lowering by Ezetimibe/Simvastatin on Outcome Incidence: Overview, Meta-Analyses, and Meta-Regression Analyses of Randomized Trials. Clin Cardiol 2015;38:763-769.

-5 Karlson BW, Palmer MK, Nicholls SJ, Lundman P, Barter PJ: Doses of rosuvastatin, atorvastatin and simvastatin that induce equal reductions in LDL-C and non-HDL-C: Results from the VOYAGER metaanalysis. Eur J Prev Cardiol 2016;23:744-747.

-6 Filippatos TD, Elisaf MS: Safety considerations with fenofibrate/simvastatin combination. Expert Opin Drug Saf 2015;14:1481-1493.

7 Gryn SE, Hegele RA: Ezetimibe plus simvastatin for the treatment of hypercholesterolemia. Expert Opin Pharmacother 2015;16:1255-1262.

-8 Ramadan WH, Kabbara WK: Sitagliptin/Simvastatin: a first combination tablet to treat type 2 diabetes and hypercholesterolemia--a review of its characteristics. Vasc Health Risk Manag 2015;11:125-132.

-9 Jiang Z, Gong RR, Qiu L, Wang Q, Su M, Liu XJ, Hu MS, Lin J, Fang DZ: Efficacy and safety of pitavastatin versus simvastatin: a meta-analysis of randomized controlled trials. Clin Drug Investig 2014;34:599-608. 


\section{Cellular Physiology Cell Physiol Biochem 2017;43:492-506 \\ \begin{tabular}{ll|l} 
DOI: 10.1159/000480476 & $\begin{array}{l}\text { O 2017 The Author(s). Published by S. Karger AG, Basel } \\
\text { www.karger.com/cpb }\end{array}$ \\
\hline and Biochemistry
\end{tabular}}

Al Mamun Bhuyan et al.: Simvastatin-Induced Eryptosis

10 Owens AP, 3rd, Byrnes JR, Mackman N: Hyperlipidemia, tissue factor, coagulation, and simvastatin. Trends Cardiovasc Med 2014;24:95-98.

-11 Steinberg H, Anderson MS, Musliner T, Hanson ME, Engel SS: Management of dyslipidemia and hyperglycemia with a fixed-dose combination of sitagliptin and simvastatin. Vasc Health Risk Manag 2013;9:273-282.

12 Naderi S, Foody JM: Ezetimibe and simvastatin for the prevention of cardiovascular events in predialysis chronic kidney disease patients: a review. Int J Nephrol Renovasc Dis 2012;5:165-169.

$\checkmark 13$ Huang X, Chen DY: A case study of single-pill combination therapy: the ezetimibe/simvastatin combination for treatment of hyperlipidemia. ChemMedChem 2012;7:1882-1894.

14 Lyseng-Williamson KA: Ezetimibe/simvastatin: a guide to its clinical use in hypercholesterolemia. Am J Cardiovasc Drugs 2012;12:49-56.

15 Filippatos TD, Elisaf MS: Fenofibrate plus simvastatin (fixed-dose combination) for the treatment of dyslipidaemia. Expert Opin Pharmacother 2011;12:1945-1958.

16 Longenberger J, Shah ZA: Simvastatin and other HMG-CoA reductase inhibitors on brain cholesterol levels in Alzheimer's disease. Curr Alzheimer Res 2011;8:434-442.

17 Barbosa CP, Bracht L, Ames FQ de Souza Silva-Comar FM, Tronco RP, Bersani-Amado CA: Effects of Ezetimibe, Simvastatin, and their Combination on Inflammatory Parameters in a Rat Model of AdjuvantInduced Arthritis. Inflammation 2016;10.1007/s10753-016-0497-x

18 Liu JN, Suh DH, Yang EM, Lee SI, Park HS, Shin YS: Attenuation of airway inflammation by simvastatin and the implications for asthma treatment: is the jury still out? Exp Mol Med 2014;46:e113.

19 Marin L, Colombo P, Bebawy M, Young PM, Traini D: Chronic obstructive pulmonary disease: pathophysiology, current methods of treatment and the potential for simvastatin in disease management. Expert Opin Drug Deliv 2011;8:1205-1220.

-20 Munoz MA, Maxwell PR, Green K, Hughes DW, Talbert RL: Pravastatin versus simvastatin for prevention of contrast-induced nephropathy. J Cardiovasc Pharmacol Ther 2011;16:376-379.

-21 Nykanen AI, Tuuminen R, Lemstrom KB: Donor simvastatin treatment and cardiac allograft ischemia/ reperfusion injury. Trends Cardiovasc Med 2013;23:85-90.

-22 Moshiri A, Sharifi AM, Oryan A: Role of Simvastatin on fracture healing and osteoporosis: a systematic review on in vivo investigations. Clin Exp Pharmacol Physiol 2016;43:659-684.

23 Montero J, Manzano G, Albaladejo A: The role of topical simvastatin on bone regeneration: A systematic review. J Clin Exp Dent 2014;6:e286-290.

24 Mirza ZB, Hu S, Amorosa LF: Bone scintigraphy of severe hypercalcemia following simvastatin induced rhabdomyolysis. Clin Cases Miner Bone Metab 2016;13:257-261.

-25 Mergenhagen K, Ott M, Heckman K, Rubin LM, Kellick K: Low vitamin D as a risk factor for the development of myalgia in patients taking high-dose simvastatin: a retrospective review. Clin Ther 2014;36:770-777.

26 Kaufman MB, Choy M: Pregabalin and simvastatin: first report of a case of rhabdomyolysis. P t 2012;37:579-595.

27 Marot A, Morelle J, Chouinard VA, Jadoul M, Lambert M, Demoulin N: Concomitant use of simvastatin and amiodarone resulting in severe rhabdomyolysis: a case report and review of the literature. Acta Clin Belg 2011;66:134-136.

-28 Hu M, Mak VW, Tomlinson B: Simvastatin-induced myopathy, the role of interaction with diltiazem and genetic predisposition. J Clin Pharm Ther 2011;36:419-425.

29 Watkins JL, Atkinson BJ, Pagliaro LC: Rhabdomyolysis in a Prostate Cancer Patient Taking Ketoconazole and Simvastatin: Case Report and Review of the Literature. Ann Pharmacother 2011;45:e9.

30 Cvetkovic Z, Suvajdzic-Vukovic N, Todorovic Z, Panic M, Neskovic A: Simvastatin and amlodipine induced thrombocytopenia in the same patient: double trouble and a literature review. J Clin Pharm Ther 2013;38:246-248.

-31 Park DS, So HS, Lee JH, Park HY, Lee YJ, Cho JH, Yoon KH, Park C, Yun K, Park R: Simvastatin treatment induces morphology alterations and apoptosis in murine cochlear neuronal cells. Acta Otolaryngol 2009;129:166-174.

-32 Gu W, Xiang L, Jiang T, Luo G, Wei J, Cen J, Chen Z, Qiu G, Zeng M, Zhang X: Changes of Apolipoprotein M Gene Expression During the Cell Differentiation and Apoptosis Induced by Simvastatin in Combination with All-Trans Retinoic Acid in Human Promyelocytic Leukemia Cell Line NB4. Indian J Hematol Blood Transfus 2016;32:54-61. 


\section{Cellular Physiology Cell Physiol Biochem 2017;43:492-506 \\ \begin{tabular}{ll|l|l} 
DOI: 10.1159/000480476 & $\begin{array}{l}\text { O 2017 The Author(s). Published by S. Karger AG, Basel } \\
\text { www.karger.com/cpb }\end{array}$ \\
\hline and Biochemistry & Published online: September 20, 2017
\end{tabular}}

Al Mamun Bhuyan et al.: Simvastatin-Induced Eryptosis

33 Huang X, Ma J, Xu J, Su Q Zhao J: Simvastatin induces growth inhibition and apoptosis in HepG2 and Huh7 hepatocellular carcinoma cells via upregulation of Notch1 expression. Mol Med Rep 2015;11:2334-2340.

-34 Tu YS, Kang XL, Zhou JG, Lv XF, Tang YB, Guan YY: Involvement of Chk1-Cdc25A-cyclin A/CDK2 pathway in simvastatin induced S-phase cell cycle arrest and apoptosis in multiple myeloma cells. Eur J Pharmacol 2011;670:356-364.

35 Wu H, Jiang H, Lu D, Xiong Y, Qu C, Zhou D, Mahmood A, Chopp M: Effect of simvastatin on glioma cell proliferation, migration, and apoptosis. Neurosurgery 2009;65:1087-1096; discussion 1096-1087.

-36 Konturek PC, Burnat G, Hahn EG: Inhibition of Barret's adenocarcinoma cell growth by simvastatin: involvement of COX-2 and apoptosis-related proteins. J Physiol Pharmacol 2007;58 Suppl 3:141-148.

-37 Koyuturk M, Ersoz M, Altiok N: Simvastatin induces proliferation inhibition and apoptosis in C6 glioma cells via c-jun N-terminal kinase. Neurosci Lett 2004;370:212-217.

-38 Ahmed TA, Hayslip J, Leggas M: Simvastatin interacts synergistically with tipifarnib to induce apoptosis in leukemia cells through the disruption of RAS membrane localization and ERK pathway inhibition. Leuk Res 2014;38:1350-1357.

-39 Ahmed TA, Hayslip J, Leggas M: Pharmacokinetics of high-dose simvastatin in refractory and relapsed chronic lymphocytic leukemia patients. Cancer Chemother Pharmacol 2013;72:1369-1374.

-40 Lai EH, Hong CY, Kok SH, Hou KL, Chao LH, Lin LD, Chen MH, Wu PH, Lin SK: Simvastatin alleviates the progression of periapical lesions by modulating autophagy and apoptosis in osteoblasts. J Endod 2012;38:757-763.

41 Lang E, Lang F: Mechanisms and pathophysiological significance of eryptosis, the suicidal erythrocyte death. Semin Cell Dev Biol 2015;39:35-42.

42 Lang PA, Kaiser S, Myssina S, Wieder T, Lang F, Huber SM: Role of Ca2+-activated K+ channels in human erythrocyte apoptosis. Am J Physiol Cell Physiol 2003;285:C1553-1560.

-43 Nguyen DB, Wagner-Britz L, Maia S, Steffen P, Wagner C, Kaestner L, Bernhardt I: Regulation of phosphatidylserine exposure in red blood cells. Cell Physiol Biochem 2011;28:847-856.

44 Nguyen DB, Ly TB, Wesseling MC, Hittinger M, Torge A, Devitt A, Perrie Y, Bernhardt I: Characterization of Microvesicles Released from Human Red Blood Cells. Cell Physiol Biochem 2016;38:1085-1099.

-45 Wesseling MC, Wagner-Britz L, Boukhdoud F, Asanidze S, Nguyen DB, Kaestner L, Bernhardt I: Measurements of Intracellular Ca2+ Content and Phosphatidylserine Exposure in Human Red Blood Cells: Methodological Issues. Cell Physiol Biochem 2016;38:2414-2425.

-46 Abed M, Towhid ST, Mia S, Pakladok T, Alesutan I, Borst O, Gawaz M, Gulbins E, Lang F: Sphingomyelinaseinduced adhesion of eryptotic erythrocytes to endothelial cells. Am J Physiol Cell Physiol 2012;303:C991999.

47 Lau IP, Chen H, Wang J, Ong HC, Leung KC, Ho HP, Kong SK: In vitro effect of CTAB- and PEG-coated gold nanorods on the induction of eryptosis/erythroptosis in human erythrocytes. Nanotoxicology 2012;6:847856.

48 Maellaro E, Leoncini S, Moretti D, Del Bello B, Tanganelli I, De Felice C, Ciccoli L: Erythrocyte caspase-3 activation and oxidative imbalance in erythrocytes and in plasma of type 2 diabetic patients. Acta Diabetol 2013;50:489-495.

-49 Bissinger R, Lang E, Ghashghaeinia M, Singh Y, Zelenak C, Fehrenbacher B, Honisch S, Chen H, Fakhri H, Umbach AT, Liu G, Rexhepaj R, Liu G, Schaller M, Mack AF, Lupescu A, Birnbaumer L, Lang F, Qadri SM: Blunted apoptosis of erythrocytes in mice deficient in the heterotrimeric G-protein subunit Galphai2. Sci Rep 2016;6:30925.

50 Zelenak C, Eberhard M, Jilani K, Qadri SM, Macek B, Lang F: Protein kinase CK1alpha regulates erythrocyte survival. Cell Physiol Biochem 2012;29:171-180.

51 Bhavsar SK, Gu S, Bobbala D, Lang F: Janus kinase 3 is expressed in erythrocytes, phosphorylated upon energy depletion and involved in the regulation of suicidal erythrocyte death. Cell Physiol Biochem 2011;27:547-556.

52 Schneider J, Nicolay JP, Foller M, Wieder T, Lang F: Suicidal erythrocyte death following cellular K+ loss. Cell Physiol Biochem 2007;20:35-44.

53 Gatidis S, Zelenak C, Fajol A, Lang E, Jilani K, Michael D, Qadri SM, Lang F: p38 MAPK activation and function following osmotic shock of erythrocytes. Cell Physiol Biochem 2011;28:1279-1286.

54 Foller M, Sopjani M, Koka S, Gu S, Mahmud H, Wang K, Floride E, Schleicher E, Schulz E, Munzel T, Lang F: Regulation of erythrocyte survival by AMP-activated protein kinase. Faseb j 2009;23:1072-1080. 


\section{Cellular Physiology Cell Physiol Biochem 2017;43:492-506 \begin{tabular}{l|l|l} 
and Biochemistry Published onlIne: September 20, 2017 & $\begin{array}{l}\text { (c) } 2017 \text { The Author(s). Published by S. Karger AG, Basel } \\
\text { www.karger.com/cpb }\end{array}$
\end{tabular} \\ Al Mamun Bhuyan et al.: Simvastatin-Induced Eryptosis}

55 Foller M, Feil S, Ghoreschi K, Koka S, Gerling A, Thunemann M, Hofmann F, Schuler B, Vogel J, Pichler B, Kasinathan RS, Nicolay JP, Huber SM, Lang F, Feil R: Anemia and splenomegaly in cGKI-deficient mice. Proc Natl Acad Sci U S A 2008;105:6771-6776.

56 Lang E, Bissinger R, Fajol A, Salker MS, Singh Y, Zelenak C, Ghashghaeinia M, Gu S, Jilani K, Lupescu A, Reyskens KM, Ackermann TF, Foller M, Schleicher E, Sheffield WP, Arthur JS, Lang F, Qadri SM: Accelerated apoptotic death and in vivo turnover of erythrocytes in mice lacking functional mitogen- and stressactivated kinase MSK1/2. Sci Rep 2015;5:17316.

\$57 Zelenak C, Foller M, Velic A, Krug K, Qadri SM, Viollet B, Lang F, Macek B: Proteome analysis of erythrocytes lacking AMP-activated protein kinase reveals a role of PAK2 kinase in eryptosis. J Proteome Res 2011;10:1690-1697.

58 Shaik N, Lupescu A, Lang F: Sunitinib-sensitive suicidal erythrocyte death. Cell Physiol Biochem 2012;30:512-522.

59 Lupescu A, Shaik N, Jilani K, Zelenak C, Lang E, Pasham V, Zbidah M, Plate A, Bitzer M, Foller M, Qadri SM, Lang F: Enhanced erythrocyte membrane exposure of phosphatidylserine following sorafenib treatment: an in vivo and in vitro study. Cell Physiol Biochem 2012;30:876-888.

60 Briglia M, Fazio A, Faggio C, Laufer S, Alzoubi K, Lang F: Triggering of Suicidal Erythrocyte Death by Ruxolitinib. Cell Physiol Biochem 2015;37:768-778.

61 Bissinger R, Barking S, Alzoubi K, Liu G, Liu G, Lang F: Stimulation of Suicidal Erythrocyte Death by the Antimalarial Drug Mefloquine. Cell Physiol Biochem 2015;36:1395-1405.

62 Bissinger R, Bouguerra G, Stockinger K, Abbes S, Lang F: Triggering of Suicidal Erythrocyte Death by Topotecan. Cell Physiol Biochem 2015;37:1607-1618.

-63 Bouguerra G, Aljanadi O, Bissinger R, Abbes S, Lang F: Embelin-Induced Phosphatidylserine Translocation in the Erythrocyte Cell Membrane. Cell Physiol Biochem 2015;37:1629-1640.

64 Bouguerra G, Bissinger R, Abbes S, Lang F: Stimulation of Eryptosis by Narasin. Cell Physiol Biochem 2015;37:1807-1816.

65 Fazio A, Briglia M, Faggio C, Alzoubi K, Lang F: Stimulation of Suicidal Erythrocyte Death by Garcinol. Cell Physiol Biochem 2015;37:805-815.

66 Briglia M, Fazio A, Signoretto E, Faggio C, Lang F: Edelfosine Induced Suicidal Death of Human Erythrocytes. Cell Physiol Biochem 2015;37:2221-2230.

67 Calabro S, Alzoubi K, Faggio C, Laufer S, Lang F: Triggering of Suicidal Erythrocyte Death Following Boswellic Acid Exposure. Cell Physiol Biochem 2015;37:131-142.

68 Egler J, Lang F: Licochalcone A Induced Suicidal Death of Human Erythrocytes. Cell Physiol Biochem 2015;37:2060-2070.

69 Faggio C, Alzoubi K, Calabro S, Lang F: Stimulation of suicidal erythrocyte death by PRIMA-1. Cell Physiol Biochem 2015;35:529-540.

70 Lang E, Jilani K, Bissinger R, Rexhepaj R, Zelenak C, Lupescu A, Lang F, Qadri SM: Vitamin D-Rich Diet in Mice Modulates Erythrocyte Survival. Kidney Blood Press Res 2015;40:403-412.

-71 Zierle J, Bissinger R, Egler J, Lang F: Lapatinib Induced Suicidal Death of Human Erythrocytes. Cell Physiol Biochem 2015;37:2275-2287.

-72 Officioso A, Alzoubi K, Manna C, Lang F: Clofazimine Induced Suicidal Death of Human Erythrocytes. Cell Physiol Biochem 2015;37:331-341.

73 Peter T, Bissinger R, Enkel S, Alzoubi K, Oswald G, Lang F: Programmed erythrocyte death following in vitro Treosulfan treatment. Cell Physiol Biochem 2015;35:1372-1380.

74 Stockinger K, Bissinger R, Bouguerra G, Abbes S, Lang F: Enhanced Eryptosis Following Exposure to Carnosic Acid. Cell Physiol Biochem 2015;37:1779-1791.

75 Waibel S, Bissinger R, Bouguerra G, Abbes S, Lang F: Saquinavir Induced Suicidal Death of Human Erythrocytes. Cell Physiol Biochem 2015;37:1973-1982.

76 Bissinger R, Bouguerra G, Al Mamun Bhuyan A, Waibel S, Abbes S, Lang F: Efavirenz Induced Suicidal Death of Human Erythrocytes. Cell Physiol Biochem 2015;37:2496-2507.

77 Bissinger R, Waibel S, Bouguerra G, Al Mamun Bhuyan A, Abbes S, Lang F: Enhanced Eryptosis Following Exposure to Lopinavir. Cell Physiol Biochem 2015;37:2486-2495.

78 Briglia M, Calabro S, Signoretto E, Alzoubi K, Laufer S, Faggio C, Lang F: Fucoxanthin Induced Suicidal Death of Human Erythrocytes. Cell Physiol Biochem 2015;37:2464-2475. 


\section{Cellular Physiology Cell Physiol Biochem 2017;43:492-506 \begin{tabular}{l|l|l|l} 
DOI: 10.1159/000480476 & (c) 2017 The Author(s). Published by S. Karger AG, Basel \\
www.karger.com/cpb
\end{tabular}

79 Briglia M, Fazio A, Faggio C, Lang F: Triggering of Suicidal Erythrocyte Death by Zosuquidar. Cell Physiol Biochem 2015;37:2355-2365.

80 Fazio A, Briglia M, Faggio C, Alzoubi K, Lang F: Oxaliplatin Induced Suicidal Death of Human Erythrocytes. Cell Physiol Biochem 2015;37:2393-2404.

81 Macczak A, Cyrkler M, Bukowska B, Michalowicz J: Eryptosis-inducing activity of bisphenol A and its analogs in human red blood cells (in vitro study). J Hazard Mater 2016;307:328-335.

82 Officioso A, Alzoubi K, Lang F, Manna C: Hydroxytyrosol inhibits phosphatidylserine exposure and suicidal death induced by mercury in human erythrocytes: Possible involvement of the glutathione pathway. Food Chem Toxicol 2016;89:47-53.

83 Officioso A, Manna C, Alzoubi K, Lang F: Bromfenvinphos induced suicidal death of human erythrocytes. Pestic Biochem Physiol 2016;126:58-63.

-84 Qadri SM, Donkor DA, Bhakta V, Eltringham-Smith LJ, Dwivedi DJ, Moore JC, Pepler L, Ivetic N, Nazi I, FoxRobichaud AE, Liaw PC, Sheffield WP: Phosphatidylserine externalization and procoagulant activation of erythrocytes induced by Pseudomonas aeruginosa virulence factor pyocyanin. J Cell Mol Med 2016;20:710720.

85 Zierle J, Bissinger R, Bouguerra G, Abbes S, Lang F: Triggering of Suicidal Erythrocyte Death by Regorafenib. Cell Physiol Biochem 2016;38:160-172.

86 Pagano M, Faggio C: The use of erythrocyte fragility to assess xenobiotic cytotoxicity. Cell Biochem Funct 2015;33:351-355.

87 Al Mamun Bhuyan A, Bissinger R, Stockinger K, Lang F: Stimulation of Suicidal Erythrocyte Death by Tafenoquine. Cell Physiol Biochem 2016;39:2464-2476.

88 Al Mamun Bhuyan A, Signoretto E, Bissinger R, Lang F: Enhanced Eryptosis Following Exposure to Dolutegravir. Cell Physiol Biochem 2016;39:639-650.

89 Al Mamun Bhuyan A, Signoretto E, Lang F: Triggering of Suicidal Erythrocyte Death by Psammaplin A. Cell Physiol Biochem 2016;39:908-918.

90 Mischitelli M, Jemaa M, Almasry M, Faggio C, Lang F: Stimulation of Erythrocyte Cell Membrane Scrambling by Quinine. Cell Physiol Biochem 2016;40:657-667.

-91 Bissinger R, Bhuyan AA, Signoretto E, Lang F: Stimulating Effect of Elvitegravir on Suicidal Erythrocyte Death. Cell Physiol Biochem 2016;38:1111-1120.

-92 Egler J, Zierle J, Lang F: Stimulating Effect of Manumycin A on Suicidal Erythrocyte Death. Cell Physiol Biochem 2016;38:1147-1156.

93 Mischitelli M, Jemaa M, Almasry M, Faggio C, Lang F: Triggering of Suicidal Erythrocyte Death by Fascaplysin. Cell Physiol Biochem 2016;39:1638-1647.

94 Mischitelli M, Jemaa M, Almasry M, Faggio C, Lang F: Ca2+ Entry, Oxidative Stress, Ceramide and Suicidal Erythrocyte Death Following Diosgenin Treatment. Cell Physiol Biochem 2016;39:1626-1637.

95 Mischitelli M, Jemaa M, Almasry M, Faggio C, Lang F: Stimulation of Suicidal Erythrocyte Death by Rottlerin. Cell Physiol Biochem 2016;40:558-566.

\$6 Mischitelli M, Jemaa M, Almasry M, Faggio C, Lang F: Triggering of Erythrocyte Cell Membrane Scrambling by Emodin. Cell Physiol Biochem 2016;40:91-103.

-97 Peter T, Bissinger R, Lang F: Stimulation of Eryptosis by Caspofungin. Cell Physiol Biochem 2016;39:939949.

98 Peter T, Bissinger R, Liu G, Lang F: Anidulafungin-Induced Suicidal Erythrocyte Death. Cell Physiol Biochem 2016;38:2272-2284.

-99 Peter T, Bissinger R, Signoretto E, Mack AF, Lang F: Micafungin-Induced Suicidal Erythrocyte Death. Cell Physiol Biochem 2016;39:584-595.

100 Pretorius E, du Plooy JN, Bester J: A Comprehensive Review on Eryptosis. Cell Physiol Biochem 2016;39:1977-2000.

101 Shan F, Yang R, Ji T, Jiao F: Vitamin C Inhibits Aggravated Eryptosis by Hydrogen Peroxide in Glucose-6Phosphated Dehydrogenase Deficiency. Cell Physiol Biochem 2016;39:1453-1462.

102 Signoretto E, Zierle J, Bissinger R, Castagna M, Bossi E, Lang F: Triggering of Suicidal Erythrocyte Death by Pazopanib. Cell Physiol Biochem 2016;38:926-938.

103 Signoretto E, Castagna M, Al Mamun Bhuyan A, Lang F: Stimulating Effect of Terfenadine on Erythrocyte Cell Membrane Scrambling. Cell Physiol Biochem 2016;38:1425-1434. 


\section{Cellular Physiology Cell Physiol Biochem 2017;43:492-506 \begin{tabular}{l|l} 
and Biochemistry & DOI: 10.1159/000480476 2017 The Author(s). Published by S. Karger AG, Basel \\
www.karger.com/cpb
\end{tabular}

Al Mamun Bhuyan et al.: Simvastatin-Induced Eryptosis

104 Signoretto E, Castagna M, Lang F: Stimulation of Eryptosis, the Suicidal Erythrocyte Death by Piceatannol. Cell Physiol Biochem 2016;38:2300-2310.

105 Signoretto E, Honisch S, Briglia M, Faggio C, Castagna M, Lang F: Nocodazole Induced Suicidal Death of Human Erythrocytes. Cell Physiol Biochem 2016;38:379-392.

106 Signoretto E, Laufer SA, Lang F: Stimulating Effect of Sclareol on Suicidal Death of Human Erythrocytes. Cell Physiol Biochem 2016;39:554-564.

107 Wesseling MC, Wagner-Britz L, Huppert H, Hanf B, Hertz L, Nguyen DB, Bernhardt I: Phosphatidylserine Exposure in Human Red Blood Cells Depending on Cell Age. Cell Physiol Biochem 2016;38:1376-1390.

108 Zierle J, Bissinger R, Lang F: Inhibition by Teriflunomide of Erythrocyte Cell Membrane Scrambling Following Energy Depletion, Oxidative Stress and Ionomycin. Cell Physiol Biochem 2016;39:1877-1890.

109 Bissinger R, Modicano P, Alzoubi K, Honisch S, Faggio C, Abed M, Lang F: Effect of saponin on erythrocytes. Int J Hematol 2014;100:51-59.

110 Bissinger R, Modicano P, Frauenfeld L, Lang E, Jacobi J, Faggio C, Lang F: Estramustine-induced suicidal erythrocyte death. Cell Physiol Biochem 2013;32:1426-1436.

111 Lang E, Modicano P, Arnold M, Bissinger R, Faggio C, Abed M, Lang F: Effect of thioridazine on erythrocytes. Toxins (Basel) 2013;5:1918-1931.

112 Al Mamun Bhuyan A, Bissinger R, Cao H, Lang F: Triggering of Suicidal Erythrocyte Death by Bexarotene. Cell Physiol Biochem 2016;40:1239-1251.

113 Almasry M, Jemaa M, Mischitelli M, Faggio C, Lang F: Stimulation of Suicidal Erythrocyte Death by Phosphatase Inhibitor Calyculin A. Cell Physiol Biochem 2016;40:163-171.

114 Alzoubi K, Egler J, Abed M, Lang F: Enhanced eryptosis following auranofin exposure. Cell Physiol Biochem 2015;37:1018-1028.

115 Jemaa M, Mischitelli M, Fezai M, Almasry M, Faggio C, Lang F: Stimulation of Suicidal Erythrocyte Death by the CDC25 Inhibitor NSC-95397. Cell Physiol Biochem 2016;40:597-607.

-116 Lang E, Pozdeev VI, Gatidis S, Qadri SM, Haussinger D, Kubitz R, Herebian D, Mayatepek E, Lang F, Lang KS, Lang PA: Bile Acid-Induced Suicidal Erythrocyte Death. Cell Physiol Biochem 2016;38:1500-1509.

117 Signoretto E, Bissinger R, Castagna M, Lang F: Stimulation of Eryptosis by Combretastatin A4 Phosphate Disodium (CA4P). Cell Physiol Biochem 2016;38:969-981.

118 Abed M, Feger M, Alzoubi K, Pakladok T, Frauenfeld L, Geiger C, Towhid ST, Lang F: Sensitization of erythrocytes to suicidal erythrocyte death following water deprivation. Kidney Blood Press Res 2013;37:567-578.

119 Voelkl J, Alzoubi K, Mamar AK, Ahmed MS, Abed M, Lang F: Stimulation of suicidal erythrocyte death by increased extracellular phosphate concentrations. Kidney Blood Press Res 2013;38:42-51.

120 Bissinger R, Artunc F, Qadri SM, Lang F: Reduced Erythrocyte Survival in Uremic Patients Under Hemodialysis or Peritoneal Dialysis. Kidney Blood Press Res 2016;41:966-977.

-121 Abed M, Artunc F, Alzoubi K, Honisch S, Baumann D, Foller M, Lang F: Suicidal erythrocyte death in endstage renal disease. J Mol Med (Berl) 2014;92:871-879.

122 Ahmed MS, Langer H, Abed M, Voelkl J, Lang F: The uremic toxin acrolein promotes suicidal erythrocyte death. Kidney Blood Press Res 2013;37:158-167.

123 Polak-Jonkisz D, Purzyc L: Ca(2+) influx versus efflux during eryptosis in uremic erythrocytes. Blood Purif 2012;34:209-210; author reply 210.

124 Calderon-Salinas JV, Munoz-Reyes EG, Guerrero-Romero JF, Rodriguez-Moran M, Bracho-Riquelme RL, Carrera-Gracia MA, Quintanar-Escorza MA: Eryptosis and oxidative damage in type 2 diabetic mellitus patients with chronic kidney disease. Mol Cell Biochem 2011;357:171-179.

125 Lang PA, Beringer O, Nicolay JP, Amon O, Kempe DS, Hermle T, Attanasio P, Akel A, Schafer R, Friedrich B, Risler T, Baur M, Olbricht CJ, Zimmerhackl LB, Zipfel PF, Wieder T, Lang F: Suicidal death of erythrocytes in recurrent hemolytic uremic syndrome. J Mol Med (Berl) 2006;84:378-388.

126 Nicolay JP, Schneider J, Niemoeller OM, Artunc F, Portero-Otin M, Haik G, Jr., Thornalley PJ, Schleicher E, Wieder T, Lang F: Stimulation of suicidal erythrocyte death by methylglyoxal. Cell Physiol Biochem 2006;18:223-232.

-127 Lang E, Gatidis S, Freise NF, Bock H, Kubitz R, Lauermann C, Orth HM, Klindt C, Schuier M, Keitel V, Reich M, Liu G, Schmidt S, Xu HC, Qadri SM, Herebian D, Pandyra AA, Mayatepek E, Gulbins E, Lang F, Haussinger D, Lang KS, Foller M, Lang PA: Conjugated bilirubin triggers anemia by inducing erythrocyte death. Hepatology 2015;61:275-284. 


\section{Cellular Physiology Cell Physiol Biochem 2017;43:492-506 \begin{tabular}{ll|l} 
and Biochemistry Published online: September 20, 2017 & $\begin{array}{l}\text { (c) } 2017 \text { The Author(s). Published by S. Karger AG, Basel } \\
\text { www.karger.com/cpb }\end{array}$ \\
\hline
\end{tabular}}

Al Mamun Bhuyan et al.: Simvastatin-Induced Eryptosis

128 Bissinger R, Schumacher C, Qadri SM, Honisch S, Malik A, Gotz F, Kopp HG, Lang F: Enhanced eryptosis contributes to anemia in lung cancer patients. Oncotarget 2016;7:14002-14014.

129 Qadri SM, Mahmud H, Lang E, Gu S, Bobbala D, Zelenak C, Jilani K, Siegfried A, Foller M, Lang F: Enhanced suicidal erythrocyte death in mice carrying a loss-of-function mutation of the adenomatous polyposis coli gene. J Cell Mol Med 2012;16:1085-1093.

130 Bissinger R, Kempe-Teufel DS, Honisch S, Qadri SM, Randrianarisoa E, Haring HU, Henes J, Lang F: Stimulated Suicidal Erythrocyte Death in Arteritis. Cell Physiol Biochem 2016;39:1068-1077.

-131 Kempe DS, Akel A, Lang PA, Hermle T, Biswas R, Muresanu J, Friedrich B, Dreischer P, Wolz C, Schumacher U, Peschel A, Gotz F, Doring G, Wieder T, Gulbins E, Lang F: Suicidal erythrocyte death in sepsis. J Mol Med (Berl) 2007;85:273-281.

132 Lang PA, Schenck M, Nicolay JP, Becker JU, Kempe DS, Lupescu A, Koka S, Eisele K, Klarl BA, Rubben H, Schmid KW, Mann K, Hildenbrand S, Hefter H, Huber SM, Wieder T, Erhardt A, Haussinger D, Gulbins E, Lang F: Liver cell death and anemia in Wilson disease involve acid sphingomyelinase and ceramide. Nat Med 2007;13:164-170.

133 Lupescu A, Bissinger R, Goebel T, Salker MS, Alzoubi K, Liu G, Chirigiu L, Mack AF, Qadri SM, Lang F: Enhanced suicidal erythrocyte death contributing to anemia in the elderly. Cell Physiol Biochem 2015;36:773-783.

134 Lang E, Pozdeev VI, Xu HC, Shinde PV, Behnke K, Hamdam JM, Lehnert E, Scharf RE, Lang F, Haussinger D, Lang KS, Lang PA: Storage of Erythrocytes Induces Suicidal Erythrocyte Death. Cell Physiol Biochem 2016;39:668-676.

135 Kamel WA, Sugihara E, Nobusue H, Yamaguchi-Iwai S, Onishi N, Maki K, Fukuchi Y, Matsuo K, Muto A, Saya H, Shimizu T: Simvastatin-Induced Apoptosis in Osteosarcoma Cells: A Key Role of RhoA-AMPK/p38 MAPK Signaling in Antitumor Activity. Mol Cancer Ther 2017;16:182-192.

136 Harrison HE, Bunting H, Ordway NK, Albrink WS: THE PATHOGENESIS OF THE RENAL INJURY PRODUCED IN THE DOG BY HEMOGLOBIN OR METHEMOGLOBIN. J Exp Med 1947;86:339-356.

137 Lee J, Hong YS, Hong JY, Han SW, Kim TW, Kang HJ, Kim TY, Kim KP, Kim SH, Do IG, Kim KM, Sohn I, Park SH, Park JO, Lim HY, Cho YB, Lee WY, Yun SH, Kim HC, Park YS, Kang WK: Effect of simvastatin plus cetuximab/ irinotecan for KRAS mutant colorectal cancer and predictive value of the RAS signature for treatment response to cetuximab. Invest New Drugs 2014;32:535-541.

138 Ijioma N, Robinson JG: Lipid-lowering effects of ezetimibe and simvastatin in combination. Expert Rev Cardiovasc Ther 2011;9:131-145.

139 Abed M, Thiel C, Towhid ST, Alzoubi K, Honisch S, Lang F, Konigsrainer A: Stimulation of Erythrocyte Cell Membrane Scrambling by C-Reactive Protein. Cell Physiol Biochem 2017;41:806-818.

140 Andrews DA, Low PS: Role of red blood cells in thrombosis. Curr Opin Hematol 1999;6:76-82.

141 Closse C, Dachary-Prigent J, Boisseau MR: Phosphatidylserine-related adhesion of human erythrocytes to vascular endothelium. Br J Haematol 1999;107:300-302.

142 Gallagher PG, Chang SH, Rettig MP, Neely JE, Hillery CA, Smith BD, Low PS: Altered erythrocyte endothelial adherence and membrane phospholipid asymmetry in hereditary hydrocytosis. Blood 2003;101:46254627.

143 Pandolfi A, Di Pietro N, Sirolli V, Giardinelli A, Di Silvestre S, Amoroso L, Di Tomo P, Capani F, Consoli A, Bonomini M: Mechanisms of uremic erythrocyte-induced adhesion of human monocytes to cultured endothelial cells. J Cell Physiol 2007;213:699-709.

144 Wood BL, Gibson DF, Tait JF: Increased erythrocyte phosphatidylserine exposure in sickle cell disease: flowcytometric measurement and clinical associations. Blood 1996;88:1873-1880.

145 Steffen P, Jung A, Nguyen DB, Muller T, Bernhardt I, Kaestner L, Wagner C: Stimulation of human red blood cells leads to Ca2+-mediated intercellular adhesion. Cell Calcium 2011;50:54-61.

146 Borst O, Abed M, Alesutan I, Towhid ST, Qadri SM, Foller M, Gawaz M, Lang F: Dynamic adhesion of eryptotic erythrocytes to endothelial cells via CXCL16/SR-PSOX. Am J Physiol Cell Physiol 2012;302:C644651.

147 Chung SM, Bae ON, Lim KM, Noh JY, Lee MY, Jung YS, Chung JH: Lysophosphatidic acid induces thrombogenic activity through phosphatidylserine exposure and procoagulant microvesicle generation in human erythrocytes. Arterioscler Thromb Vasc Biol 2007;27:414-421.

148 Zwaal RF, Comfurius P, Bevers EM: Surface exposure of phosphatidylserine in pathological cells. Cell Mol Life Sci 2005;62:971-988. 